\title{
Islamic Banking Performance: \\ A Bibliometric Review
}

\author{
Greget Kalla Buana
}

Durham University and United Nation Development Programme

ORCID: 0000-0002-2591-3522

\author{
Fahmi Ali Hudaefi \\ Institut Agama Islam Darussalam (IAID) Ciamis, West Jawa, Indonesia \\ ORCID: 0000-0002-1557-837X
}

Rezzy Eko Caraka*

Department of Statistics, Seoul National University, Korea

ORCID: 0000-0002-1812-7478

Corresponding Author : rezzy94@snu.ac.kr

\begin{abstract}
Islamic banks (IBs) have been criticized as not being genuinely Islamic, and the methods in measuring their performances have been debatable. While the literature on IBs performance has been emerging, such studies precisely assess its recent development remains absent. Therefore, we aim to evaluate the development of scholarly articles that measure IBs' performances. We employ bibliometric analysis and sample related articles from the Scopus database. We find that the development of IBs performance literature may be understood by 111 peer-reviewed journal articles, 4 conference papers, 1 book, and 1 book series. We analyze these materials based on publication sources, country and institution affiliation, keywords association, and cluster dendrogram. Our model that quantifies the keywords association and cluster dendrogram provides a novelty in assessing IBs performance literature development. Future studies may replicate our model to cluster and identify the keyword associations from the unstructured data sources.
\end{abstract}

Keywords: Islamic bank, banking performance, bibliometric analysis, cluster

\section{Declarations}

- Funding There's no funding for our research.

- Conflicts of interest/Competing interests We confirm that there is no conflict of interest in our manuscript.

- Availability of data and material

The datasets analysed are available in www.scopus.com

\section{- Code availability}

In scopus.com, the data can be searched by using the keyword; Islamic bank, and under the result of this keyword, the keyword; performance is further typed.

- Authors' contributions

All authors contribute equally. 


\title{
Islamic Banking Performance: A Bibliometric Review
}

\begin{abstract}
Islamic banks (IBs) have been criticized as not being genuinely Islamic, and the methods in measuring their performances have been debatable. While the literature on IBs performance has been emerging, such studies precisely assess its recent development remains absent. Therefore, we aim to evaluate the development of scholarly articles that measure IBs' performances. We employ bibliometric analysis and sample related articles from the Scopus database. We find that the development of IBs performance literature may be understood by 111 peer-reviewed journal articles, 4 conference papers, 1 book, and 1 book series. We analyze these materials based on publication sources, country and institution affiliation, keywords association, and cluster dendrogram. Our model that quantifies the keywords association and cluster dendrogram provides a novelty in assessing IBs performance literature development. Future studies may replicate our model to cluster and identify the keyword associations from the unstructured data sources.
\end{abstract}

Keywords: Islamic bank, banking performance, bibliometric analysis, cluster

\section{Introduction}

The functioning of Mit Ghamr Local Savings Banks in Egypt from 1963 to 1967 is believed as a pioneering experiment of the current development of the Islamic banking industry worldwide (Maali and Napier 2010; Haniffa and Hudaib 2010; Hafsa Orhan Åström 2013; Jinjiri Ringim 2014; Alharbi 2017; Islam and Rahman 2017; Shome et al. 2018; Lujja et al. 2018; Mohammed et al. 2019; Farooq 2019; ElMassah et al. 2019; Pitchay et al. 2019; Chamberlain et al. 2020). According to a report by Islamic Financial Services Board (2020), the global Islamic banks (IBs) assets in 2019 increased by 12.7 percent (year-on-year), with total assets amounting to USD 1.77 trillion (as per quarter 3 of 2019).

Despite having indicated considerable growth, IBs have been criticized over decades. Costumer's skepticism continues to appear (Ashraf and Lahsasna 2017). The expressions of dissent within the IBs ecosystem can be lined up into two points. First, IBs are claimed not Islamic for being operated under conventional fiat money as in Zaim Zaidi's non-academic book titled; Tidak Syar 'inya Bank Syariah di Indonesia (Islamic banks in Indonesia are not genuinely Islamic). Second, IBs do not promote the Islamic moral economy's aspiration due to the excessive profitmaximizing, and thus seem to fail socially (Asutay 2008 2012). Furthermore, the dynamics of the banking industry and the Sharīah status of a bank that cannot be measured in absolute terms (Ashraf and Lahsasna 2017) has been the impetus for employing different approaches in measuring the IBs performance.

How to accurately and objectively measure the IBs performance? Some researchers rely on the use of conventional benchmarks, while others have developed methods for investigating the nature of IBs. Such divergence in evaluating IBs performance leads to a debate among experts on how to measure IBs performance correctly (Mohammed and Razak 2008; Muhammad and Taib 2015; Hudaefi and Noordin 2019).

In light of these differing opinions, a bibliometric analysis that assesses the degree to which scholarly works have discussed the IBs performance remains absent. At the time this study is conducted in November 2020, bibliometric analysis on the topic of Islamic banking and finance is yet to address a specific issue on IBs performance. Contemporary researches broadly covered 
Islamic banking and finance (IBF) in general (Biancone et al. 2020), literature review on IBs sustainability (Aliyu et al. 2017), and an evaluation of takāful (Islamic insurance) literature (Khan et al. 2020).

Against the background above, we aim to examine Islamic economics and finance writings in international peer-reviewed journals, particularly the articles related to Islamic banking performance. It is expected that both theoretical and practical implications from this study will contribute to IBs performance discourse. This study is relevant for academics, professionals, and other stakeholders of IBs to gain insight into the development of peer-reviewed articles concerning the IBs performance.

The rest of this paper is structured as follows. The next part conceptualizes Islamic banking performance. Section 2 explains the research method. Section 3 discusses the results. Section 4 presents the discussion. Future research direction and conclusion are drawn in the final sections.

\subsection{Conceptualising Islamic banking performance and research question}

The presence of IBs is expected to articulate Sharī'ah (Islamic law) into practice in the banking industry (Hassan and Lewis 2007; Ashraf and Lahsasna 2017; Hanif 2018; Hudaefi and Noordin 2019). It brings philosophical consequences beyond a mere commercial transaction. However, there are no standardized tools to measure IBs' performance (Ascarya et al. 2017). IBs generally apply financial ratios and efficiency as performance measurement, similar to those in conventional banks (CBs).

Besides profitability using the ratio of Return on Assets (ROA), Return on Equity (ROE), Return on Investment (ROI), and Net Profit Margin (NPM), CAMELS is the most common rating system to rate financial institutions. It is based on capital adequacy, asset quality, management, earnings, liquidity, and sensitivity measurements. Taking into account, several studies have merged conventional approach and Sharī'ah measurement to evaluate IBs performance (Hudaefi and Noordin 2019) by modifying the 'S' with Sharī'ah indicators (Muljawan 2005; Sarker 2006; Ratnaputri 2013; Rahman and Masngut 2014; Ismail and Pa 2015; Hudaefi and Noordin 2019). Nevertheless, the replacement of ' $S$ ' is deemed inadequate (Hudaefi and Noordin 2019).

Internal financial performance of IBs is also demonstrated in comparison with CBs using Financial Ratio Analysis (FRA) in terms of profitability, liquidity, solvency, and credit risk. Macroeconomic variables, such as inflation, GDP, interest rate, and unemployment, are complementary (Kouser and Saba 2012; Erol et al. 2014; Ifeacho and Ngalawa 2014; Hadriche 2015; Rashid and Jabeen 2016; Suresh and Bardastani 2016.

In relevance to IBs objective and concerning religious beliefs, alternative measurements were developed. For example; the incorporation of Islamicity disclosure (Ibrahim et al. 2004; Ascarya et al. 2017), Islamicity Performance Index (Meilani et al. 2016; Mutia et al. 2019), ethical identity (Haniffa and Hudaib 2007), Islamic moral economy (Asutay and Harningtyas 2015), and Maqāṣid al-Sharī'ah (the objective of Islamic law) (Mohammed et al. 2008; Hudaefi and Noordin 2019). These studies represent the novelty in measuring IBs performance adopted from Islamic theory.

Taken all together, given numerous articles have been emerging to measure the IBs performance, an investigation using a bibliometric approach is theoretically important to understand such recent development. On this basis, we, therefore, ask the following question; RQ - How is the development of peer-reviewed scholarly articles discussing the IBs performance? 


\section{Methods}

2.1. Bibliometric analysis

At the heart of social sciences, algorithms such as bibliometric analysis, including inferential statistics combined with a qualitative approach, have been increasingly used by academics and researchers (Khan et al. 2020). However, on the subject of IBF, such techniques are novel given the number of studies employing the method is severely limited, moreover in discussing the progress of research on IBs performance.

To better understand the development of literature on IBs performance (RQ), we first conduct this quantitative bibliometric analysis. We executed the meta-analysis by sampling the Scopus database. Scopus is the largest abstract and citation database of peer-reviewed literature; hence, this database's selection is relevant. In IBF-related bibliometric studies, Biancone et al (2020) have used this database to evaluate IBF literature.

The bibliometric analysis procedures consist of two core analyses; sample selection and bibliometric citation analysis (Çoğaltay and Karadağ 2015, Olczyk 2016, Biancone et al. 2020; Khan et al. 2020). There are three analytical steps in bibliometric citation analysis: co-citation analysis, citation analysis, and co-authorship (Olczyk 2016, Biancone et al. 2020; Khan et al. 2020). Figure 1 depicts our steps in performing bibliometric analysis, which primarily followed Khan et al. (2020) with additional keywords association and cluster dendrogram analyses.

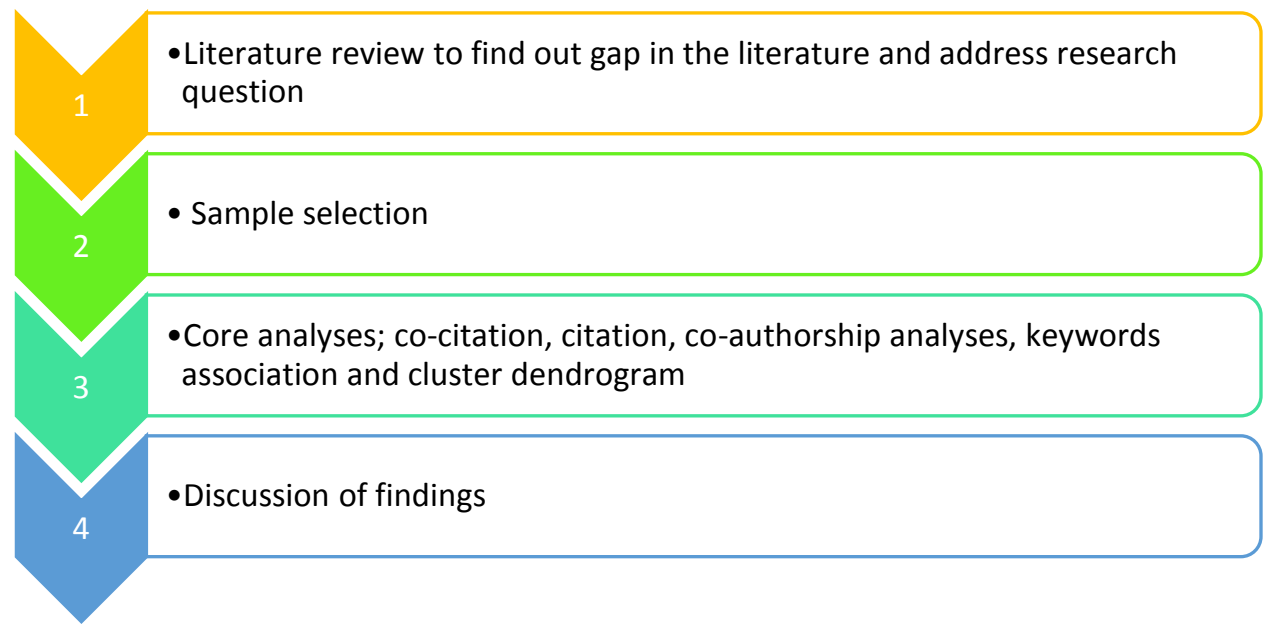

Source: Adopted from Çoğaltay and Karadağ (2015), Olczyk (2016), Biancone et al. (2020), Khan et al. (2020).

Figure 1. Analytical steps in a bibliometric study

\subsubsection{Sample selection process}

The analysis began with the procedures of meta-analysis review as outlined by Çoğaltay and Karadağ (2015), Biancone et al. (2020), and Khan et al. (2020). In the first step, we used the keyword; 'Islamic banking' and 'Islamic banks' to sample relevant articles from the Scopus database. We used another keyword, 'performance,' to gain specific articles on Islamic banking performance.

Our first step resulted in 118 articles which were published between 2009 to early 2020. During the process of generating data, we did not find scholarly articles published in 2011. We then labeled the data. The derivative of other keywords was obtained and pre-processed before the analysis. 
Figure 2 depicts the development of scholarly articles published on IBs performance in the Scopus database.

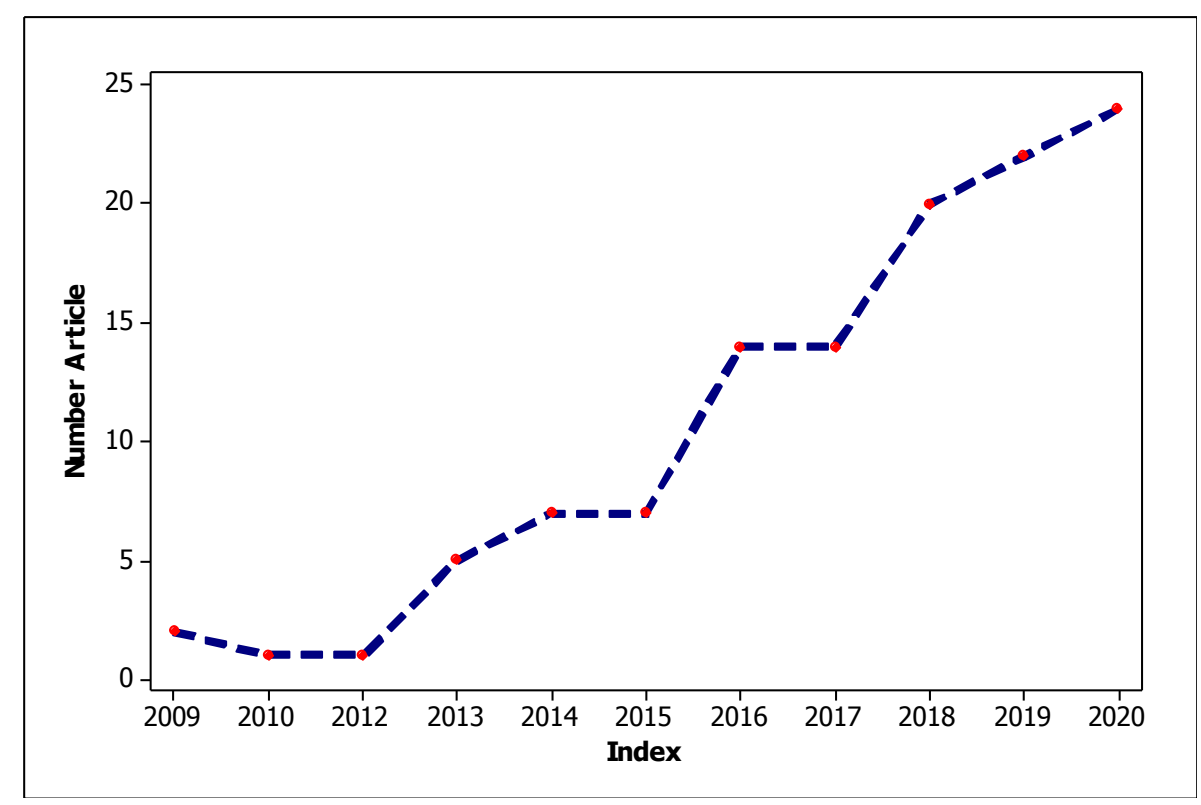

Source: Authors' analysis.

Figure 2. The trend of publications related to Islamic banking performance on the Scopus database

\subsubsection{Clustering on Meta-Analysis}

Caraka et al. (2021) explain that the hierarchical algorithm makes hierarchical decomposition of several objects in the form of agglomerative (bottom-up) or divisive (top-down). In simple terms, agglomerative starts with each object representing itself as a cluster. Furthermore, each object which shares similar information is combined based on the distance value (Lawson and Denison 2002). This clustering process stops as the number of groups is determined (Moore 2001).

Unlike the divisive algorithm, this technique starts from a group that contains all objects that have information on themselves into one cluster. This technique is similar to the conqueror and divide algorithms (Kaban et al. 2019). The similarity concept can be used to answer how close or how far objects are from other objects. The more similar two objects are, the greater the similarity between them.

Furthermore, distance can be measured using one of the distance variations, or in statistics is known as a metric. According to Cios et al. (2007), for the three points data $\hat{x}, \hat{y}$, and $\hat{z}$ where all these points are within $d$ then distance $d$ must meet the following conditions:

- $d(\hat{x}, \hat{y}) \geq:$ Non - negativity;

- $d(\hat{x}, \hat{y})=0$ : only and only if $\hat{x}=\hat{y}$ identity ;

- $d(\hat{x}, \hat{y})=d(\hat{x}, \hat{y}):$ symmetry ;

- $d(\hat{x}, \hat{z}) \leq d(\hat{x}, \hat{y})+d(\hat{y}, \hat{z})$ : triangle inequality. 
The distance metric is used to calculate $\hat{x}$ and $\hat{y}$ with numeric attributes can be used using Minkowski Distance with $q$ is a positive integer (Caraka and Yasin 2017). It is formulated as following equation $1(\mathrm{Eq} 1)$ :

$$
d(\hat{x}, \hat{y})=\left(\sum_{i=1}^{n}\left|x_{i}-y_{i}\right|^{q}\right)^{\frac{1}{q}}
$$

The above approach allows us to cluster the keywords related to IBs performance. To perform this, first, we calculated the distance by $\mathrm{Eq}(1)$. We used R Software with the igraph library package (Csardi and Nepusz 2006), ggraph (Pedersen 2017), ggplot2 (Wickham 2009), and STATCAL (Gio and Caraka 2019). The information used was co-occurrences within 3 words distance.

We noted that raw co-occurrence data, including the detected frequency signatures, offers some evidence of repeated term combinations. Such repetition mainly occurs in the form of cooccurrence frequencies. Thus, we did a sampling replacement on data extracted from the corpus as random sampling from our population. Furthermore, given the likelihood (Caraka et al. 2020) of co-occurrence represented by random variables $J$ and $K$, the random collection of a class of pair from some kind of population is represented. For any pair type $t=(j, k)$, it can be defined as following equation 2 (Eq2):

$$
\operatorname{Pr}(J=j \wedge K=k)=\pi_{t}
$$

The probabilities $\operatorname{Pr}(J=j)=: \pi_{1, j}$ and $\operatorname{Pr}(K=k)=: \pi_{2, k}$ represent as marginal probabilities from the component $j$ and $K$. Meanwhile, in case the population is entirely determined by the probability of the parameter $\pi_{t}$, it is therefore formulated in equation 3 (Eq3):

$$
\pi_{1, j}=\sum_{j^{\prime} \in C_{2}} \pi_{\left(u, k^{\prime}\right)} \text { and } \pi_{2, k}=\sum_{k^{\prime} \in C_{1}} \pi_{\left(u^{\prime}, k\right)}
$$

\section{Results}

\subsection{Publication related to Islamic banking performance in the Scopus database}

Table 1 explains the number of related publications we have gained from the Scopus database. As depicted in Figure 3, it consists of 111 peer-reviewed journal articles (95 percent), 4 conference papers ( 3 percent), 1 book ( 1 percent), and 1 book series ( 1 percent). Overall, we found that most of the publication related to IBs performance was peer-reviewed journal articles. Our analysis identified the top 4 journals which covered the keywords of IBs performance. Those journals are International Journal of Islamic and Middle Eastern Finance and Management with 7 articles, Journal of Islamic Accounting and Business Research with 6 articles, Banks and Bank Systems and International Journal of Financial Research with 4 articles, respectively.

Figure 4 illustrates the percentage of each publication source contribution to the IBs performance literature. Of the total publication we have identified, 64.1 percent was contributed by 63 sources (57 academic journals, 4 conference papers, 1 book, and 1 book series), 6 percent by International Journal of Islamic and Middle Eastern Finance and Management, 5.1 percent by Journal of Islamic Accounting and Business Research, 3.4 percent by Banks and Bank Systems and International Journal of Financial Research, and 2.6 percent by Asian Social Science Corporate Governance Bingley, Humanomics, International Journal of Economics and Financial Issues, International Journal of Supply Chain Management, Journal of Business Ethics, and Journal of Financial Crime. 
Table 1. List of Sources Published Articles Related to Islamic Banking Performance

\begin{tabular}{|c|c|}
\hline Title Sources & Papers \\
\hline International Journal of Islamic and Middle Eastern Finance and Management & 7 \\
\hline Journal of Islamic Accounting and Business Research & 6 \\
\hline Banks and Bank Systems & 4 \\
\hline International Journal of Financial Research & 4 \\
\hline Asian Social Science & 3 \\
\hline Corporate Governance Bingley & 3 \\
\hline Humanomics & 3 \\
\hline International Journal of Economics and Financial Issues & 3 \\
\hline International Journal of Supply Chain Management & 3 \\
\hline Journal of Business Ethics & 3 \\
\hline Journal of Financial Crime & 3 \\
\hline Al Shajarah & 2 \\
\hline Cogent Business and Management & 2 \\
\hline Hamdard Islamicus & 2 \\
\hline International Journal of Business Governance and Ethics & 2 \\
\hline International Journal of Economics and Management & 2 \\
\hline International Journal of Innovative Technology and Exploring Engineering & 2 \\
\hline International Journal of Learning and Intellectual Capital & 2 \\
\hline Journal of Economic Cooperation and Development & 2 \\
\hline Journal of Islamic Marketing & 2 \\
\hline Journal of King Abdulaziz University Islamic Economics & 2 \\
\hline Jurnal Pengurusan & 2 \\
\hline Managerial Finance & 2 \\
\hline 2020 6th IEEE International Conference on Information Management (ICIM 2020) & 1 \\
\hline $\begin{array}{l}\text { 2nd International Symposium on Technology Management and Emerging } \\
\text { Technologies (ISTMET) } 2015 \text { Proceeding }\end{array}$ & 1 \\
\hline Academy of Accounting and Financial Studies Journal & 1 \\
\hline Accounting Research Journal & 1 \\
\hline Advanced Science Letters & 1 \\
\hline Applied Economics & 1 \\
\hline Borsa Istanbul Review & 1 \\
\hline Contemporary Issues on Business Development and Islamic Economics in Indonesia & 1 \\
\hline Contemporary Studies in Economic and Financial Analysis & 1 \\
\hline DLSU Business and Economics Review & 1 \\
\hline Global Journal Al Thaqafah & 1 \\
\hline Humanities and Social Sciences Reviews & 1 \\
\hline Indian Journal of Public Health Research and Development & 1 \\
\hline Intellectual Discourse & 1 \\
\hline International Journal of Bank Marketing & 1 \\
\hline International Journal of Business Information Systems & 1 \\
\hline International Journal of Civil Engineering and Technology & 1 \\
\hline International Journal of Economic Perspectives & 1 \\
\hline International Journal of Economic Research & 1 \\
\hline
\end{tabular}




\begin{tabular}{|c|c|}
\hline Title Sources & Papers \\
\hline International Journal of Finance and Economics & 1 \\
\hline International Journal of Innovation and Sustainable Development & 1 \\
\hline International Journal of Management Practice & 1 \\
\hline International Journal of Monetary Economics and Finance & 1 \\
\hline International Journal of Scientific and Technology Research & 1 \\
\hline International Journal of Services Economics and Management & 1 \\
\hline International Review of Economics and Finance & \\
\hline Investment Management and Financial Innovations & 1 \\
\hline ISRA International Journal of Islamic Finance & 1 \\
\hline Journal of Accounting Auditing and Finance & 1 \\
\hline Journal of Asian Finance Economics and Business & 1 \\
\hline Journal of Financial Reporting and Accounting & 1 \\
\hline Journal of Financial Services Research & 1 \\
\hline Journal of International Financial Markets Institutions and Money & 1 \\
\hline Journal of Islamic Economics Banking and Finance & \\
\hline Journal of Management Development & \\
\hline Journal of Open Innovation Technology Market and Complexity & 1 \\
\hline Journal of the Knowledge Economy & 1 \\
\hline Natural Product Reports & 1 \\
\hline Pacific Accounting Review & 1 \\
\hline Pacific Basin Finance Journal & 1 \\
\hline Pertanika Journal of Social Sciences and Humanities & 1 \\
\hline Polish Journal of Management Studies & 1 \\
\hline Problems and Perspectives in Management & 1 \\
\hline $\begin{array}{l}\text { Proceedings of the 30th International Business Information Management Association } \\
\text { Conference (IBIMA 2017) }\end{array}$ & 1 \\
\hline $\begin{array}{l}\text { Proceedings of the International Conference on Industrial Engineering and Operations } \\
\text { Management }\end{array}$ & 1 \\
\hline Quarterly Review of Economics and Finance & 1 \\
\hline Qudus International Journal of Islamic Studies & \\
\hline Research in World Economy & 1 \\
\hline Review of Development Finance & 1 \\
\hline Review of Financial Economics & 1 \\
\hline Review of Radical Political Economics & 1 \\
\hline Social Sciences Pakistan & 1 \\
\hline
\end{tabular}

Source: Scopus.com. Searched using the following keywords; Islamic banking, Islamic banks, and performance. The search was done on 21 November 2020. 


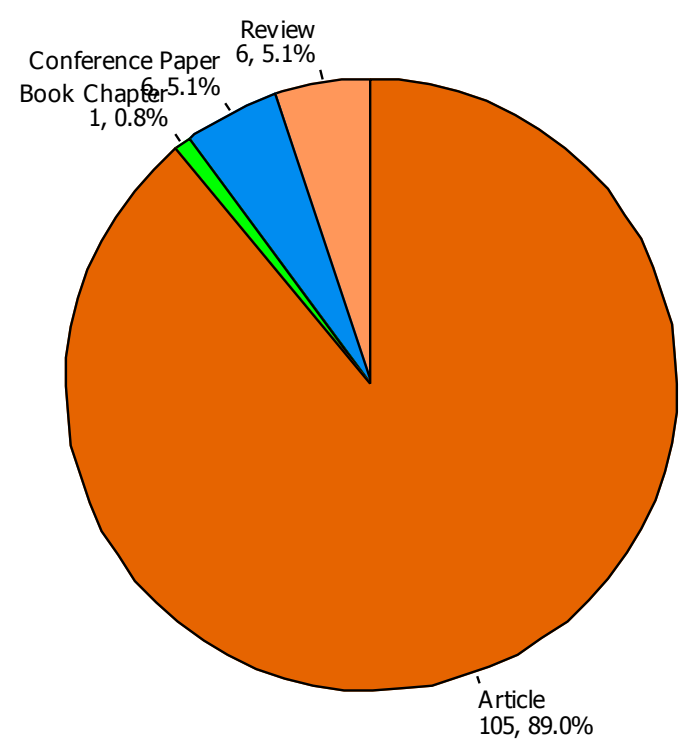

Source: Authors' analysis.

Figure 3. Percentage of Islamic banking performance related literature based on document types

\subsection{Country and institution affiliation}

We further performed a country-level analysis, which associates with the publication of literature related to IBs performance. Of the total 153 counts during the analysis, we identified Malaysia as the country with the highest output of IBs performance publication by 20.3 percent. That was followed by Indonesia (13.7 percent), United Kingdom (8.5 percent), Tunisia (6.5 percent), Bahrain and the United Arab Emirates, respectively by 5.9 percent, and Pakistan and Saudi Arabia, respectively, by 5 percent. Figure 4 visualizes the percentage of each country's contribution to the literature of IBs performance on a world map. The countries colored with pale and deep green contributed between $0.7-8.5$ percent to the IBs performance literature. The countries colored with blue and dark blue contributed to $13.7-20.3$ percent.

Furthermore, we identified the top 6 contributors' institutions. International Islamic University Malaysia leads as the highest contributors' affiliation. That was followed by Universiti Utara Malaysia, University of Malaya, University of Sfax, Universitas Airlangga, and International Islamic University Chittagong, respectively. Table 2 illustrates the percentage of the top 6 contributors' affiliations. 
Source: Authors' analysis using www.datawrapper.de. The detailed version of the map visualization can be accessed here; https://datawrapper.dwcdn.net/GSdvk/1/

Figure 4. Percentage of contribution to the literature of IBs performance based on country-level analysis

Table 1. Top 6 Institutions Published Islamic Banking Performance Literature

Source: Authors' analysis.

\begin{tabular}{|l|r|}
\hline Affiliation & Count \\
\hline International Islamic University Malaysia & 16 \\
\hline Universiti Utara Malaysia & 6 \\
\hline University of Malaya & 5 \\
\hline University of Sfax & 5 \\
\hline Universitas Airlangga & 4 \\
\hline International Islamic University Chittagong & 4 \\
\hline
\end{tabular}

\subsection{Keywords association and cluster dendrogram}

We further identified the association between keyboards using Eq(1). Words such as; Islamic banking, banking performance, data panels, shari'ah supervisory board, and profitability were associated with IBs performance. Furthermore, we identified the most widely used statistical methods in IBs performance research; logistic regression models, satisfaction analysis, and credit analysis. Meanwhile, in case studies, we found that Malaysia, Bangladesh, Bahrain, Indonesia, Pakistan, Oman, and the United Arab Emirates, were mostly mentioned in IBs performance literature.

Figure 7 shows the association between several keywords with Size $=174$, Density $=0.005$, Transitivity $=0$, Diameter $=2$, Degree Centralization $=0.253$, Average path length $=1.968$. We used dendrogram to detail the keywords that were extensively used in IBs Performance literature. Furthermore, Figure 8 illustrates cluster dendrogram by sub-keywords generated at the IBs performance. We used round $(0.90 *$ length (Count Keyword $))$ to generate 13 clusters. 
1

2

3

4

5

6

7

8

9

10

11

12

13

14

15

16

17

18

19

20

21

22

23

24

25

26

27

28

29

30

31

32

33

34

35

36

37

38

39

40

41

42

43

44

45

46

47

48

49

50

51

52

53

54

55

56

57

58

59

60

61

62

63

64

65

Source: Authors' analysis.

Efficiency Zinancial Crisis
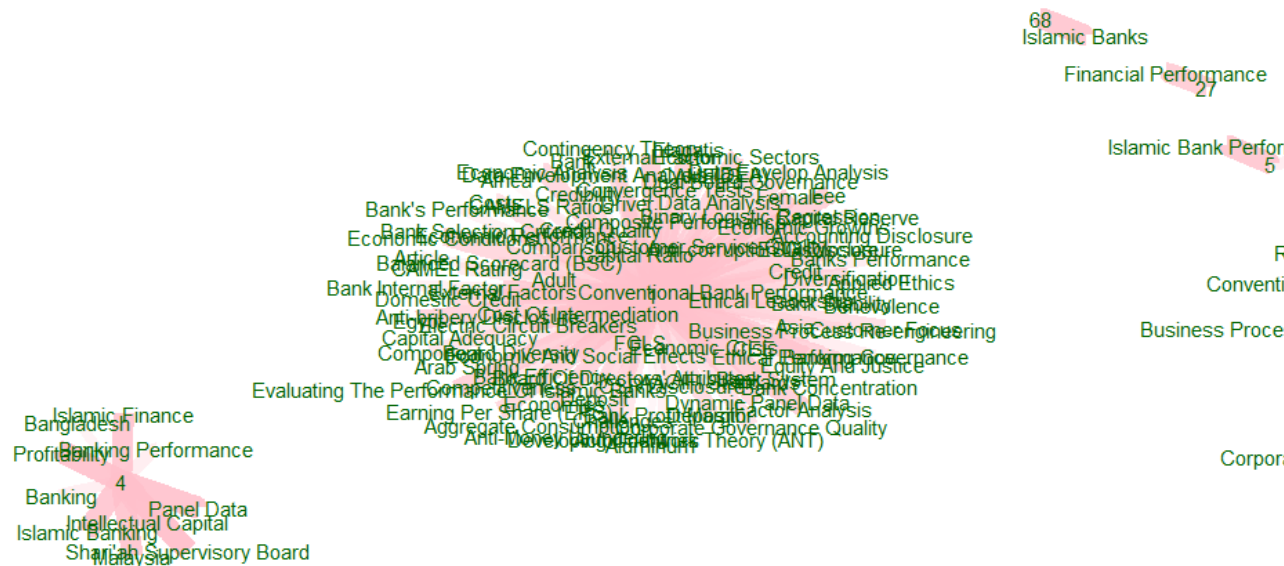

Islamic Bank Performance

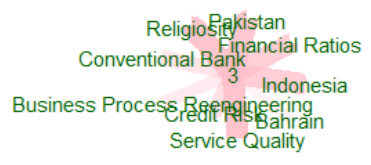

Corporate Governance ${ }^{6}$ Countries

15

$\stackrel{20}{\text { Bank Performance }}$

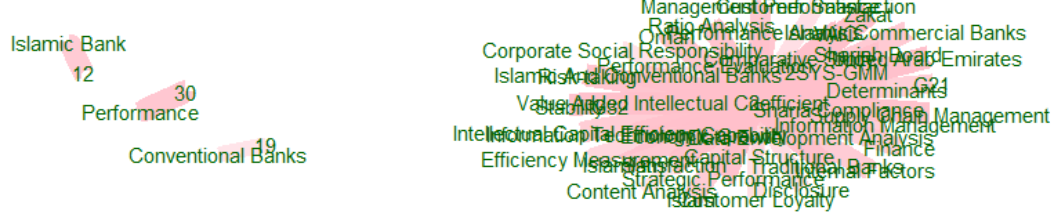

Figure 7. Co-occurrences within 3 words distance

Source: Authors' analysis.

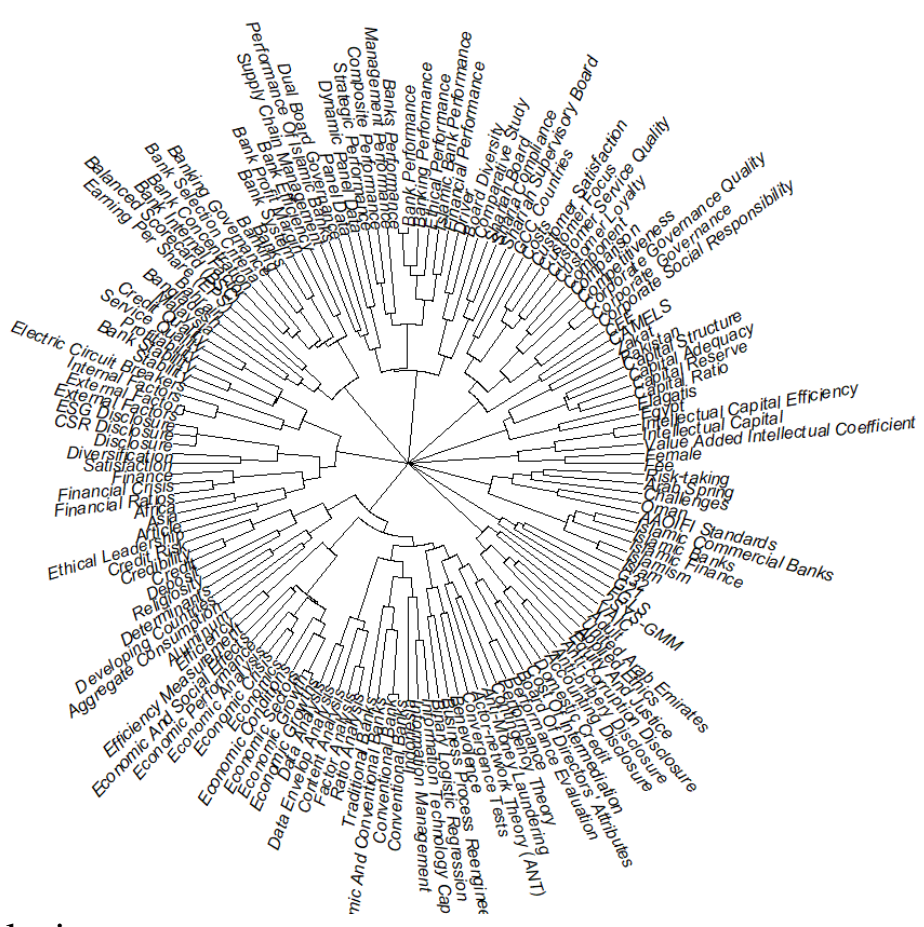

Figure 8. Cluster dendrogram 


\section{Discussion}

With annual average growth by 15-30 percent (Antonio et al. 2012), IBs account for the largest chunk of the Islamic finance industry and become an important and integral part of the worldwide financial sector. However, IBs have no standardized measurement model to evaluate performance appropriateness and relevance to its Islamic principles, which are expected to boost the economy. Since 2009 after the financial crisis, IBs have been well-thought-of playing a role as an alternative system in substitute of CBs. This is evidenced by the keyword conventional banking dominating scientific research on IBs performance after Islamic banks, performance, financial performance, and bank performance.

In relation to the crisis, IBs are also appraised as more resilient than CBs (Kassim and Shabri 2010; Hasan and Dridi 2011; Khediri et al. 2015; Hussien et al. 2019) keyword financial crisis was mentioned significantly following the two performance measurement parameters: financial performance and efficiency (see Figure 7). Nonetheless, the resilience claim in IBs is questionable given another study shows that Islamic financial institutions — 43 banks included — are not immune from the effect of global crisis (Zarrouk et al. 2016). Further elaboration is required on whether this sort of comparison imposes a different attitude toward specific financial ratios in the context of crisis.

Scholarly works have massively used the conventional approach in measuring IBs and CBs performance. Such studies have mainly addressed banking performance related to; asset quality (Khan et al. 2017; Cham 2018), capital adequacy (Abdul Karim et al. 2014; Karminsky and Kostrov 2014; Moudud-Ul-Huq 2019), earnings (Hutapea and Kasri 2010; Ismal 2010a; Lahrech et al. 2014; Arham et al. 2020), efficiency (Hassan 2006; Hassan et al. 2009; Basílio et al. 2016; Khan et al. 2017; Cham 2018; Nguyen and Vo (2020), governance (Ben Slama Zouari and Boulila Taktak 2014; Mollah et al. 2017; Ajili and Bouri 2018; Buallay 2019; Khan and Zahid 2020), regulation structure (Ahmad and Hassan 2007; Nastiti and Kasri 2019), liquidity (Samad and Hassan 2006; Ismal 2010b; Khan et al. 2017), management quality (Lahrech et al. 2014; Bukair and Abdul Rahman 2015; Khan et al. 2017; Ousama et al. 2019), profitability (Samad and Hassan 2006; Ismal 2010a; Hanafi et al. 2013; Ben Selma Mokni and Rachdi 2014; Zarrouk et al. 2016; Khan et al. 2017; Cham 2018), social responsibility measures (Farook et al. 2011; Sairally 2013) and others issues related to macroeconomic variables.

\subsection{Recent approaches in measuring Islamic banking performances}

Practically, IBs products are often characterized as Sharī'ah-based and Sharīah-compliant (Hassan and Lewis 2007; Ashraf and Lahsasna 2017; Hanif 2018). Sharī' ah-based refers to IBs products utilizing the contracts of mushärakah (capital partnership) and muḍärabah (a partnership of capital and labor) that create economic substance as both involve risk and reward (Hassan and Lewis 2007; Ashraf and Lahsasna 2017; Hanif 2018). Meanwhile, Sharī'ah-compliant refers to IBs products that engage murābahah (sale with mark-up), salam (purchasing asset with deferred delivery), istișna $\bar{a}^{\prime}$ (manufacturing) and ijärah (renting an asset) (Hassan and Lewis 2007; Hanif 2018).

Regardless of product types, such practices created a set of risks for IBs; credit and Sharīah compliance risks (Hassan and Lewis 2007; Ashraf and Lahsasna 2017). Such different risks faced by CBs and IBs imply a different approach to measuring their performances. Existing scholarly works in measuring IBs performance can be classified into three streams;

- employment of conventional benchmark to measure the IBs financial performance,

- modification of the existing conventional method by adding Sharī ah aspects, and 


\subsubsection{Employment of conventional benchmark to measure the IBs financial performance} Islamic finance essentially differs from conventional finance on the prohibition of rib $\bar{a}$ (interest charging), which distinguishes IBs from CBs. However, IBs are continuously accused of mimicking CBs in terms of product development. Thus, the word riba is barely seen as a distinctive value that is supposedly cited in many scientific researches. Comparing the performance of IBs and $\mathrm{CBs}$ has since then been the mainstream IBs performance measurement approach. This justifies the use of conventional benchmarks (i.e., financial ratios and efficiency) to measure IBs financial performance instead of deeply diving from Sharīa ah perspective.

The competition between IBs and CBs has also increased due to the growing Islamic Finance appetite. Countries or regions with full government support to Islamic finance and IBs and advanced ecosystems (e.g., regulation, institutionalization) undoubtedly contribute a lot to the sector's development. Figure 5 demonstrates Malaysia's and Indonesia's contribution to IBs performance literature. Iran and Saudi Arabia that share more than half of IBs total assets (PuriMirza 2020) are surprisingly left behind.

To some extent, there is possibly an additional key driver in Malaysia's and Indonesia's case. These two South-east Asian nations hold the 2nd and 3rd position of the world's largest Islamic Finance course provider, letting the UK top the chart (TheCityUK 2017). This confirms the UK's blue spectrum in Figure 5. That being said, there are only 5 fully Sharī'ah-compliant banks licensed in the UK. Research by Mud orange (2020) revealed that two-thirds of UK British Muslims could not recall an IB when asked. Again, that also confirms the UK's low exposure to IBs performance literature.

IBs are characterized as having higher stability for its less fluctuation in rates of returns, inflation, and other economic considerations (Karim and Ali 1989; Turen 1995; Čihák and Hesse 2010). However, not all macroeconomic indicators have a remarkable impact on performance. Even so, the external performance of IBs can be measured by the public confidence in addition to market share and regulatory compliance. On this subject, different regions experienced different effects as it is driven by domestic stability and security.

\subsubsection{Modification of existing conventional method by adding Sharī ah aspects}

Investigation of IBs performance can be without any comparison to CBs, either by independent banking indicator (e.g., bank size) or Sharī'ah aspects. On efficiency, Ahmad and Noor (2010) elaborate through a study on 78 IBs in 25 countries. IBs performance is positively associated with loan intensity, size, and capitalization. IBs with higher market share and low non-performing loans ratio are more technically efficient banks. The more efficient banks, the more profitable. This kind of assessment involves an internal parameter without comparing to CBs.

Moving to other parameters, social good and good corporate governance (GCG) are understood as part of the Sharī ah context. With respect to Islam, IBs drive transparency and accountability, which brought into social justice, wealth, and mașlahah (public welfare). Otherwise, poor corporate governance will result in negative affect and tangible environmental consequences. Again, GCG influences profitability. In addition to using GCG, Sharī ah Supervisory Board (SSB) appears undoubtedly in Figure 7 in assessing IBs performance. SSB is included in bank management to assure IBs performance in compliance with Sharīa ah. 
Apart from SSB, corporate social responsibility (CSR) is also crucial to IBs. Any business entity established within the Islamic law (in this case, IBs) are expected to follow the Islamic worldview, which encourages the principle of social and economic justice (Dusuki 2011). Those involved in IBs regard ethics and social responsibility commitment more enduring as for being connected with divine (transcendental) relation. The concept of CSR also demonstrates the presence of mașlahah brought by IBs to be socially impactful.

\subsubsection{Development of benchmark based on the Islamic theories}

The issue of costumers' skepticism on Sharī'ah compliance leads to Sharī'ah risk faced by IBs, given many violations of Sharīah norms exist in CBs. It then imposes the IBs to put concern on the Sharī'ah risk rating model. It comprises regulatory support, quality of Sharī'ah supervision, business structure (legal incorporation), product mix, and treatment of capital adequacy ratio (Ashraf and Lahsasna 2017). Figure 7 shows a few strongly related components to this issue, such as Sharī'ah compliance and SSB.

Moving forward, ethical values are an integral part of Sharī‘ah of which IBs performance can be linked to. Ethical performance based on Maqāșid al-Sharī'ah, which includes faith, life, intellect, posterity, and wealth, promotes human welfare, and enhance social and economic stability. For the reason, this ethical performance measurement is able to eliminate bias between financial and economic domains. The word ethical performance is presented in the cluster dendrogram (Figure 8) along with equity and justice and economic and social effects.

Islamicity disclosure index and Islamicity performance index (Ibrahim et al. 2004) are advanced measures. Islamicity disclosure index consists of Sharīah compliance, corporate governance, and social or environment. The three indicators are found in the cluster dendrogram with environmental, social, and corporate governance (ESG) disclosure represents social or environmental aspects. On corporate governance, the presence of SSB distinguishes IBs from CBs.

More specific on a religious basis, zakat is mentioned in the formulation of IBs performance measurements. Zakat performance ratio is one variable in the Islamicity index (Ibrahim et al. 2004) and IBs social performance (Setiawan 2009). Zakat in the financial statement is a distinctive feature to IBs as part of a financial statement. In this case, zakat paid by IBs is to replace earning per share (EPS). The wealthier the IBs are, the higher zakat the IBs must pay (Ibrahim et al. 2004). Both zakat and EPS are also in the dendrogram (Figure 8).

Incorporating religious features in IBs' performance measurement is necessary to avoid the failure in investigating Sharī' ah tenets. IBs' elements of religiosity can be in the form of integrated Maqāșid al-Sharī'ah-based performance measure (Hudaefi and Noordin 2019) or Maqāṣid alSharī'ah index (Mohammed et al. 2008). The Maqāșid al-Sharī'ah helps to determine whether IBs are practicing Islamic principles (Dusuki and Bouheraoua 2011). However, such measurement tools do not cover conventional profitability and efficiency, which are financial performance elements. Thus, a comprehensive development of a benchmark that involves both financial and religious aspects is crucial in measuring IBs performance.

\section{Future Research Direction}

Our bibliometric analysis has studied the development of IBs performance literature in the Scopus database. Similar to Hudaefi and Noordin (2019); we identified the three streams in measuring IBs performance; employing conventional benchmarks, modifying the existing conventional method, and developing benchmarks based on Islamic theories. Figure 7 and Figure 8 can also explain that in most published papers, the author only uses statistical methods very simple to calculate bank 
performance such as multiple regression analysis, logistic analysis, contingency table. This method has very limited reasoning and provides important information for decision making. In line with this, We did not find scholarly articles that have used data mining or IoT (Internet of Things) techniques and big data during the analysis. This technique can discover and produce much important information for decision making (Provost and Fawcett 2013). Studies have been emerging in using this technique to measure CBs performance. For instance; an evaluation of CSR, green credit, and corporate performance (He et al. 2019), an analysis of profit and cost (Mitik et al. 2017), an assessment of credit risk (Moradi and Mokhatab Rafiei 2019), an exploration of internet banking user (Mansingh et al. 2013) and many others. Such use of IoT (Internet of Things) or data mining and big data practically implies to the IBs performance studies. That is, in addition to the recent three streams in measuring IBs performance, future studies may take the benefit from such techniques.

\section{Conclusion and recommendation}

Returning to our RQ - How is the development of peer-reviewed scholarly articles discussing the IBs performance? - we are now possible to answer this question. We have employed a bibliometric analysis and sampled the Scopus database to address our RQ. We found the recent development of IBs performance literature consisting of 111 peer-reviewed journal articles, 4 conference papers, 1 book, and 1 book series. These sources were analyzed based on publication sources, country and institution affiliation, keywords association, and cluster dendrogram. This analysis helps us to understand the recent development of IBs performance literature in the Scopus database. Furthermore, we contextualized our findings into three streams in measuring IBs performance. Such discussions draw a comprehensive direction for future studies. Our model quantifies the keywords association, and cluster dendrogram provides a novelty in assessing IBs performance literature using a bibliometric approach. Future studies may replicate our model to cluster and identify the keyword associations from an unstructured data source. Nevertheless, our model claims several limitations. Our selection of only the Scopus database has the potential not to capture significant publications related to IBs performance measurement in other databases. Thus, future studies may engage other scholarly databases, such as ISI and Google Scholar, for a more comprehensive sample.

\section{References}

Abdul Karim M, Hassan MK, Hassan T, Mohamad S (2014) Capital adequacy and lending and deposit behaviors of conventional and Islamic banks. Pacific Basin Financ J 28:58-75. https://doi.org/10.1016/j.pacfin.2013.11.002

Ahmad AUF, Hassan MK (2007) Regulation and performance of Islamic banking in Bangladesh. Thunderbird Int Bus Rev 49:251-277. https://doi.org/10.1002/tie.20142

Ahmad NH, Noor MANM (2010) The Determinants Efficiency and Profitability of World Islamic Banks. In: International Conference on E-business, Management and Economics

Ajili H, Bouri A (2018) Corporate governance quality of Islamic banks: measurement and effect on financial performance. Int J Islam Middle East Financ Manag 11:470-487. https://doi.org/10.1108/IMEFM-05-2017-0131

Alharbi AT (2017) Determinants of Islamic banks' profitability: international evidence. Int J Islam Middle East Financ Manag 10:331-350. https://doi.org/10.1108/IMEFM-12-20150161 
Aliyu S, Hassan MK, Mohd Yusof R, Naiimi N (2017) Islamic Banking Sustainability: A Review of Literature and Directions for Future Research. Emerg Mark Financ Trade 53:440-470. https://doi.org/10.1080/1540496X.2016.1262761

Allah Pitchay A Bin, Mohd Thas Thaker MA Bin, Azhar Z, et al (2019) Factors persuade individuals' behavioral intention to opt for Islamic bank services: Malaysian depositors' perspective. J Islam Mark 11:234-250. https://doi.org/10.1108/JIMA-02-2018-0029

Antonio MS, Sanrego YD, Taufiq M (2012) An Analysis of Islamic Banking Performance: Maqashid Index Implementation in Indonesia and Jordania. J Islam Financ 1:12-29

Arham, N., Salisi, M.S., Mohammed, R.U. et al. (2020) Impact of macroeconomic cyclical indicators and country governance on bank non-performing loans in Emerging Asia. Eurasian Econ Rev 10: 707-726. https://doi.org/10.1007/s40822-020-00156-z

Ascarya, Hakim C., Rahmawati S (2017) Merancang Indeks Maqashid Bank Syariah (Formulating Islamic Bank Maqashid Index). Jakarta

Ashraf MA, Lahsasna A (2017) Proposal for a new Shar̄̄'ah risk rating approach for Islamic banks. ISRA Int J Islam Financ 9:87-94. https://doi.org/10.1108/IJIF-07-2017-008

Asutay M (2012) Conceptualising and Locating the Social Failure of Islamic Finance: Aspirations of Islamic Moral Economy vs the Realities of Islamic Finance. Asian African Area Stud 11:93-113

Asutay M (2008) Islamic Banking and Finance: Social Failure. New Horiz. https://doi.org/10.2139/ssrn.1735674

Asutay M, Harningtyas AF (2015) Developing Maqasid al-Shari'ah Index to Evaluate Social Performance of Islamic Banks: A Conceptual and Empirical Attempt. Int J Islam Econ Financ Stud 1:5-64

Basílio, M.S., Pires, M.C.P., Reis, J.F.P. (2016) Portuguese banks’ performance: comparing efficiency with their Spanish counterparts. Eurasian Econ Rev 6, 27-44. https://doi.org/10.1007/s40822-015-0033-6

Ben Selma Mokni R, Rachdi H (2014) Assessing the bank profitability in the MENA region: A comparative analysis between conventional and Islamic bank. Int J Islam Middle East Financ Manag 7:305-332. https://doi.org/10.1108/IMEFM-03-2013-0031

Ben Slama Zouari S, Boulila Taktak N (2014) Ownership structure and financial performance in Islamic banks: Does bank ownership matter? Int J Islam Middle East Financ Manag 7:146160. https://doi.org/10.1108/IMEFM-01-2013-0002

Biancone P Pietro, Saiti B, Petricean D, Chmet F (2020) The bibliometric analysis of Islamic banking and finance. J Islam Account Bus Res. https://doi.org/10.1108/JIABR-08-20200235

Buallay A (2019) Corporate governance, Sharia'ah governance and performance: A crosscountry comparison in MENA region. Int J Islam Middle East Financ Manag 12:216-235. https://doi.org/10.1108/IMEFM-07-2017-0172

Bukair AA, Abdul Rahman A (2015) Bank performance and board of directors attributes by Islamic banks. Int J Islam Middle East Financ Manag 8:291-309. https://doi.org/10.1108/IMEFM-10-2013-0111

Caraka RE, Lee Y, Chen RC, et al (2021) Cluster around Latent Variable for Vulnerability towards Natural Hazards, Non-Natural Hazards, Social Hazards in West Papua. IEEE Access. https://doi.org/10.1109/ACCESS.2020.3038883 
Caraka RE, Lee Y, Chen RC, Toharudin T (2020) Using Hierarchical Likelihood towards Support Vector Machine: Theory and Its Application. IEEE Access 8:194795-194807. https://doi.org/10.1109/ACCESS.2020.3033796

Caraka RE, Yasin H (2017) Geographically Weighted Regression (GWR) Sebuah Pendekatan Regresi Geografis, 1st edn. MOBIUS GRAHA ILMU, Yogyakarta

Cham T (2018) Determinants of Islamic banking growth: an empirical analysis. Int J Islam Middle East Financ Manag 11:18-39. https://doi.org/10.1108/IMEFM-01-2017-0023

Chamberlain T, Hidayat S, Khokhar AR (2020) Credit risk in Islamic banking: evidence from the GCC. J Islam Account Bus Res 11:1055-1081. https://doi.org/10.1108/JIABR-09-20170133

Čihák M, Hesse H (2010) Islamic Banks and Financial Stability: An Empirical Analysis. J Financ Serv Res 38:95-113. https://doi.org/10.1007/s10693-010-0089-0

Cios KJ, Pedrycz W, Swiniarski RW, Kurgan LA (2007) Data mining: A knowledge discovery approach

Çoğaltay N, Karadağ E (2015) Introduction to meta-analysis. In: Leadership and Organizational Outcomes: Meta-Analysis of Empirical Studies

Csardi G, Nepusz T (2006) The igraph software package for complex network research. InterJournal Complex Syst 1695:1-9

Dusuki AW (2011) Ethical and Social Responsibility Models for Islamic Finance

Dusuki AW, Bouheraoua S (2011) The Framework of Maqasid Al-Shariah and Its Implication for Islamic Finance. Islam Civilisational Renewal, Int Shariah Res Acad Islam Financ 2:316-336

ElMassah S, AlSayed O, Bacheer SM (2019) Liquidity in the UAE Islamic banks. J Islam Account Bus Res 10:679-694. https://doi.org/10.1108/JIABR-02-2017-0018

Erol C, Baklaci HF, Aydoğan B, Tunç G (2014) Performance comparison of islamic (participation)banks and commercial banks in Turkish banking sector. EuroMed J Bus. https://doi.org/10.1108/EMJB-05-2013-0024

Farook S, Kabir Hassan M, Lanis R (2011) Determinants of corporate social responsibility disclosure: the case of Islamic banks. J Islam Account Bus Res 2:114-141. https://doi.org/10.1108/17590811111170539

Farooq MO (2019) Rent-seeking behaviour and zulm (injustice/exploitation) beyond ribā-interest equation. ISRA Int J Islam Financ 11:110-123. https://doi.org/10.1108/IJIF-07-2018-0073

Gio PU, Caraka RE (2019) Membuat Berbagai Grafik dengan STATCAL

Hadriche M (2015) Banks Performance Determinants: Comparative Analysis between Conventional and Islamic Banks from GCC Countries. Int J Econ Financ. https://doi.org/10.5539/ijef.v7n9p169

Hafsa Orhan Åström Z (2013) Survey on customer related studies in Islamic banking. J Islam Mark 4:294-305. https://doi.org/10.1108/JIMA-07-2012-0040

Hanafi, M.M., Santi, F., Muazaroh (2013) The Impact of Ownership Concentration, Commissioners on Bank Risk and Profitability: Evidence from Indonesia. Eurasian Econ Rev 3:183-202. https://doi.org/10.14208/eer.2013.03.02.005

Hanif M (2018) Sharī'ah-compliance ratings of the Islamic financial services industry: a quantitative approach. ISRA Int J Islam Financ. https://doi.org/10.1108/IJIF-10-2017-0038

Haniffa R, Hudaib M (2010) Islamic finance: From sacred intentions to secular goals? J Islam Account Bus Res 1:85-91. https://doi.org/10.1108/17590811011086697 
Haniffa R, Hudaib M (2007) Exploring the Ethical Identity of Islamic Banks via Communication in Annual Reports. J Bus Ethics 76:97-116. https://doi.org/10.1007/s10551-006-9272-5

Hasan M, Dridi J (2011) The Effects of the Global Crisis on Islamic and Conventional Banks: A Comparative Study. J Int Commer Econ Policy. https://doi.org/10.1142/s1793993311000270

Hassan MK (2006) The X-Efficiency in Islamic Banks . Islam Econ Stud 13:

Hassan MK, Lewis MK (2007) Handbook of Islamic Banking. Edward Elgar, Cheltenham

Hassan T, Mohamad S, Khaled I. Bader M (2009) Efficiency of conventional versus Islamic banks: evidence from the Middle East. Int J Islam Middle East Financ Manag 2:46-65. https://doi.org/10.1108/17538390910946267

He L, Wu C, Yang X, Liu J (2019) Corporate social responsibility, green credit, and corporate performance: an empirical analysis based on the mining, power, and steel industries of China. Nat Hazards 95:73-89. doi: 10.1007/s11069-018-3440-7

Hudaefi FA, Noordin K (2019) Harmonizing and constructing an integrated maqāșid al-Sharī'ah index for measuring the performance of Islamic banks. ISRA Int J Islam Financ 11:282302. https://doi.org/10.1108/IJIF-01-2018-0003

Hussien ME, Alam MM, Murad MW, Wahid A (2019) The performance of Islamic banks during the 2008 global financial crisis Evidence from the Gulf Cooperation Council countries. J Islam Account Bus Res 10:1-14. https://doi.org/10.1108/JIABR-01-2017-0011

Hutapea EG, Kasri RA (2010) Bank margin determination: a comparison between Islamic and conventional banks in Indonesia. Int J Islam Middle East Financ Manag 3:65-82. https://doi.org/10.1108/17538391011033870

Ibrahim SHBM, Wirman A, Alrazi B, et al (2004) Alternative Disclosure and Performance Measures for Islamic Banks. In: The 2nd International Conference on Administrative Sciences. King Fahd University of Petroleum and Minerals.

Ifeacho C, Ngalawa H (2014) Performance of the South African banking sector since 1994. J Appl Bus Res. https://doi.org/10.19030/jabr.v30i4.8663

Islam JU, Rahman Z (2017) Awareness and willingness towards Islamic banking among Muslims: An Indian perspective. Int J Islam Middle East Financ Manag 10:92-101. https://doi.org/10.1108/IMEFM-01-2016-0017

Islamic Financial Services Board (2020) Islamic Financial Services Industry (IFSI) Stability Report 2020. Kuala Lumpur

Ismail AG, Pa ASC (2015) Financial Soundness Indicators and the Objectives of Shari'ah in Assessing the Stability of Islamic Banks. The Islamic Research and Teaching Institute (IRTI)

Ismal R (2010a) Volatility of the returns and expected losses of Islamic bank financing. Int $\mathbf{J}$ Islam Middle East Financ Manag 3:267-279. https://doi.org/10.1108/17538391011072453

Ismal R (2010b) Assessment of liquidity management in Islamic banking industry. Int J Islam Middle East Financ Manag 3:147-167. https://doi.org/10.1108/17538391011054381

Jinjiri Ringim K (2014) Perception of Nigerian Muslim account holders in conventional banks toward Islamic banking products. Int J Islam Middle East Financ Manag 7:288-305. https://doi.org/10.1108/IMEFM-04-2013-0045

Kaban PA, Kurniawan R, Caraka RE, et al (2019) Biclustering method to capture the spatial pattern and to identify the causes of social vulnerability in Indonesia: A new recommendation for disaster mitigation policy. Procedia Comput Sci 157:31-37. https://doi.org/10.1016/j.procs.2019.08.138 
Karim RAA, Ali AE (1989) Determinants of the Financial Strategy of Islamic Banks. J Bus Financ Account 16:193-212. https://doi.org/10.1111/j.1468-5957.1989.tb00013.x

Karminsky, A.M., Kostrov, A. (2014) The probability of default in Russian banking. Eurasian Econ Rev 4, 81-98. https://doi.org/10.1007/s40822-014-0005-2

Kassim SH, Shabri M (2010) Impact of financial shocks on Islamic banks: Malaysian evidence during 1997 and 2007 financial crises. Int J Islam Middle East Financ Manag 3:291-305. https://doi.org/10.1108/17538391011093243

Khan A, Hassan MK, Paltrinieri A, et al (2020) A bibliometric review of takaful literature. Int Rev Econ Financ 69:389-405. https://doi.org/10.1016/j.iref.2020.05.013

Khan I, Khan M, Tahir M (2017) Performance comparison of Islamic and conventional banks: empirical evidence from Pakistan. Int J Islam Middle East Financ Manag 10:419-433. https://doi.org/10.1108/IMEFM-05-2016-0077

Khan I, Zahid SN (2020) The impact of Shari'ah and corporate governance on Islamic banks performance: evidence from Asia. Int J Islam Middle East Financ Manag 13:483-501. https://doi.org/10.1108/IMEFM-01-2019-0003

Khediri K Ben, Charfeddine L, Youssef S Ben (2015) Islamic versus conventional banks in the GCC countries: A comparative study using classification techniques. Res Int Bus Financ 33:75-98. https://doi.org/10.1016/j.ribaf.2014.07.002

Kouser R, Saba I (2012) Gauging the financial performance of banking sector using CAMEL model: Comparison of conventional, mixed and pure Islamic banks in Pakistan. Int Res $\mathbf{J}$ Financ Econ

Lahrech N, Lahrech A, Boulaksil Y (2014) Transparency and performance in Islamic banking: Implications on profit distribution. Int J Islam Middle East Financ Manag 7:61-88. https://doi.org/10.1108/IMEFM-06-2012-0047

Lawson AB, Denison DGT (2002) Spatial cluster modelling: An overview. In: Spatial Cluster Modelling

Lujja S, Mohammed MO, Hassan R (2018) Islamic banking: an exploratory study of public perception in Uganda. J Islam Account Bus Res 9:336-352. https://doi.org/10.1108/JIABR01-2015-0001

Maali B, Napier C (2010) Accounting, religion and organisational culture: the creation of Jordan Islamic Bank. J Islam Account Bus Res 1:92-113. https://doi.org/10.1108/17590811011086705

Mansingh G, Rao L, Osei-Bryson KM, Mills A (2013) Profiling internet banking users: A knowledge discovery in data mining process model based approach. Inf Syst Front 17:193215. doi: 10.1007/s10796-012-9397-2

Meilani SER, Andraeny D, Rahmayati A (2016) Analisis Kinerja Perbankan Syariah di Indonesia dengan Menggunakan Pendekatan Islamicity Indices

Mitik M, Korkmaz O, Karagoz P, et al (2017) Data Mining Approach for Direct Marketing of Banking Products with Profit/Cost Analysis. Rev Socionetwork Strateg 11:17-31. doi: 10.1007/s12626-017-0002-5

Mohammed MO, Razak DA (2008) The Performance Measures of Islamic Banking Based on the. IIUM Int Account Conf (INTAC IV), Putra Jaya Marroitt

Mohammed NF, Mohd Fahmi F, Ahmad AE (2019) The need for Islamic accounting standards: the Malaysian Islamic financial institutions experience. J Islam Account Bus Res 10:115133. https://doi.org/10.1108/JIABR-12-2015-0059 
Mollah S, Hassan MK, Al Farooque O, Mobarek A (2017) The governance, risk-taking, and performance of Islamic banks. J Financ Serv Res 51:195-219. https://doi.org/10.1007/s10693-016-0245-2

Moore a (2001) K-means and Hierarchical Clustering. Stat Data Min Tutorials

Moradi S, Mokhatab Rafiei F (2019) A dynamic credit risk assessment model with data mining techniques: evidence from Iranian banks. Financ Innov 5:1-27. doi: 10.1186/s40854-0190121-9

Moudud-Ul-Huq, S. (2019) Banks' capital buffers, risk, and efficiency in emerging economies: are they counter-cyclical?. Eurasian Econ Rev 9:467-492. https://doi.org/10.1007/s40822018-0121-5

Mudorange (2020) Money Matters. London

Muhammad MO, Taib FM (2015) Developing Islamic Banking Performance Measures Based on Maqasid al-Shariah Framework: Cases of 24 selected Banks. J. Islam. Monet. Econ. Financ. 1:55-77

Muljawan D (2005) A Design for Islamic Banking Rating System: An Integrated Approach. IRTI-IDB

Mutia E, Jannah R, Rahmawaty R (2019) Islamicity Performance Index of Islamic Banking in Indonesia. In: proceedings of the 1st Aceh Global Conference

Nastiti ND, Kasri RA (2019) The role of banking regulation in the development of Islamic banking financing in Indonesia. Int J Islam Middle East Financ Manag 12:643-662. https://doi.org/10.1108/IMEFM-10-2018-0365

Nguyen, T.L.A., Vo, X.V. (2020) Does corporate governance really matter for bank efficiency? Evidence from ASEAN countries. Eurasian Econ Rev 10:681-706. https://doi.org/10.1007/s40822-020-00151-4

Olczyk, M. A (2016) Systematic retrieval of international competitiveness literature: a bibliometric study. Eurasian Econ Rev 6:429-457. https://doi.org/10.1007/s40822-0160054-9

Ousama AA, Hammami H, Abdulkarim M (2019) The association between intellectual capital and financial performance in the Islamic banking industry: An analysis of the GCC banks. Int J Islam Middle East Financ Manag 13:75-93. https://doi.org/10.1108/IMEFM-05-20160073

Pedersen TL (2017) R: Package 'ggraph.' Cran

Provost F, Fawcett T (2013) Data Science and its Relationship to Big Data and Data-Driven Decision Making. Big Data 1:51-59. https://doi.org/10.1089/big.2013.1508

Puri-Mirza A (2020) Distribution of global Islamic banking assets in the 3rd quarter of 2019, by country

Rahman RA, Masngut MY (2014) The Use of CAMELS in Detecting Financial Distress of Islamic Banks in Malaysia. J Appl Bus Res Vol 30, Number 2, 445-452

Rashid A, Jabeen S (2016) Analyzing performance determinants: Conventional versus Islamic Banks in Pakistan. Borsa Istanbul Rev. https://doi.org/10.1016/j.bir.2016.03.002

Ratnaputri W (2013) The Analysis of Islamic Bank Financial Performance by Using Camel, Shariah Conformity And Profitability (SCnP). J Din Manaj 4:. https://doi.org/10.15294/jdm.v4i2.2765

Sairally BS (2013) Evaluating the corporate social performance of Islamic financial institutions: an empirical study. Int J Islam Middle East Financ Manag 6:238-260. https://doi.org/10.1108/IMEFM-02-2013-0026 
Samad A, Hassan MK (2006) The Performance of Malaysian Islamic Bank During 1984-1997: An Exploratory Study. nternational J Islam Financ Serv 1:. https://doi.org/10.2139/ssrn.3263331

Sarker AA (2006) CAMELS Rating System in the Context of Islamic Banking: A Proposed "S" for Shariah Framework. J Islam Econ Bank Financ 2:1-26

Setiawan AB (2009) Analisis Kesehatan Finansial dan Kinerja Sosial Bank Syariah di Indonesia (Analysis of Financial Performance and Social Performance of Islamic Banks in Indonesia). Paramadina University

Shome A, Jabeen F, Rajaguru R (2018) What drives consumer choice of Islamic banking services in the United Arab Emirates? Int J Islam Middle East Financ Manag 11:79-95. https://doi.org/10.1108/IMEFM-03-2017-0066

Suresh C, Bardastani M (2016) Financial Performance Of Selected Conventional And Islamic Banks In Kingdom Of Bahrain - A CAMEL Ranking Based Approach. Eur J Econ Law Polit. https://doi.org/10.19044/elp.v3no1a2

TheCityUK (2017) Global Trends in Islamic Finance and the UK Market. London

Turen S (1995) Performance and Risk Analysis of the Islamic Banks:The Case of Bahrain Islamic Bank. J King Abdulaziz Univ Econ 8:3-14. https://doi.org/10.4197/islec.7-1.1

Wickham H (2009) Ggplot2: Elegant Graphics for Data Analysis, Springer.

Zarrouk H, Ben Jedidia K, Moualhi M (2016) Is Islamic bank profitability driven by same forces as conventional banks? Int J Islam Middle East Financ Manag 9:46-66.

https://doi.org/10.1108/IMEFM-12-2014-0120 